\title{
Effect of prepartum anionic supplementation on periparturient feed intake, health, and milk production
}

\author{
M. A. DeGroot, ${ }^{* 1}$ E. Block, $t^{2}$ and P. D. French ${ }^{* 3}$ \\ *Department of Animal Sciences, Oregon State University, Corvallis 97331 \\ †Arm \& Hammer Animal Nutrition, 469 N. Harrison St., Princeton, NJ 08543
}

\begin{abstract}
Our objectives were to determine if dietary cationanion difference (DCAD) and source of anions influence periparturient feed intake and milk production of dairy cattle during the transition period. Diets differed in DCAD (cationic or anionic) and anionic supplement. The 4 diets used prepartum were (1) control [DCAD $+20 \mathrm{mEq} / 100 \mathrm{~g}$ of dry matter (DM)], (2) Bio-Chlor (DCAD -12 mEq/100 g of DM; Church \& Dwight Co. Inc., Princeton, NJ), (3) Fermenten (DCAD -10 $\mathrm{mEq} / 100 \mathrm{~g}$ of DM; Church \& Dwight Co. Inc.), and (4) salts (DCAD $-10 \mathrm{mEq} / 100 \mathrm{~g}$ of $\mathrm{DM})$. Urine $\mathrm{pH}$ was lower for cows that consumed an anionic diet prepartum compared with control. Prepartum diet had no effect on prepartum dry matter intake (DMI) of multiparous or primiparous cows. Postpartum DMI and milk yield for multiparous cows fed anionic diets prepartum were greater compared with those fed the control diet. Postpartum DMI and milk yield of primiparous cows were similar for prepartum diets. Feeding prepartum anionic diets did not affect plasma $\mathrm{Ca}$ at or near calving. However, cows fed anionic diets began their decline in plasma Ca later than control cows. Postpartum $\beta$-hydroxybutyrate and nonesterified fatty acids were lower for primiparous cows fed prepartum anionic diets compared with those fed the control diet. Prepartum and postpartum plasma glucose concentrations were not affected by prepartum diet for all cows. Liver triglyceride differed for parity by day. Parities were similar at $21 \mathrm{~d}$ prepartum, but at $0 \mathrm{~d}$ and $21 \mathrm{~d}$ postpartum, levels were greater for multiparous cows. Results indicate that decreasing the DCAD of the diet during the prepartum period can increase postpartum DMI and milk production of multiparous cows without negatively affecting performance of primiparous cows.
\end{abstract}

\footnotetext{
Received January 19, 2010.

Accepted July 27, 2010.

${ }^{1}$ Current address: DeGroot Nutritional Consulting, 5916 West Vine Ct., Visalia, CA 93291.

${ }^{2}$ Corresponding author: Elliot.Block@churchdwight.com

${ }^{3}$ Current address: The Old Mill - Troy, 1247 Evon Rd., Bon Air, VA 23235 .
}

Key words: periparturient, dietary cation-anion difference, milk production, transition cow

\section{INTRODUCTION}

The transition period, as defined by Grummer (1995), is the $3 \mathrm{wk}$ before and after parturition. The transition period is considered the most difficult time of the annual cycle of the dairy cow (Keady et al., 2001), determining the cow's health, production, and reproduction in the subsequent lactation. At or near calving, most cows experience some degree of hypocalcemia (Horst et al., 1997). Clinical hypocalcemia or milk fever affects up to $9 \%$ of dairy cows (Goff et al., 1987). In a 2007 survey (USDA, 2007), 83.5\% of all dairies in the United States reported clinical milk fever as a health problem with an incidence rate of $4.9 \%$. Guard (1996) estimated the average cost per case of milk fever to be $\$ 334$. In addition, cows with milk fever are susceptible to secondary disorders, such as ketosis, mastitis, retained placenta, and displaced abomasums (Curtis et al., 1983).

Several nutritional strategies have been used in the prevention of hypocalcemia, including Ca restriction during the prepartum period (Goings et al., 1974) and decreasing the DCAD $\{\mathrm{mEq}[(\mathrm{Na}+\mathrm{K})-(\mathrm{Cl}+\mathrm{S})] / 100$ $\mathrm{g}$ of DM\} during the last 3 to 4 wk of gestation (Block, 1984; Goff and Horst, 1997b). Because of the difficulty in formulating very low calcium diets, recent interest has focused on DCAD (Horst et al., 1997). Although decreasing DCAD through removal of cations is effective in preventing hypocalcemia (Goff and Horst, 1997a), this generally precludes the use of farm-grown forages high in potassium. The alternative to lowering the DCAD of prepartum diets is to feed anionic salts $\left[\mathrm{MgSO}_{4}, \mathrm{MgCl}_{2}, \mathrm{NH}_{4} \mathrm{Cl},\left(\mathrm{NH}_{4}\right)_{2} \mathrm{SO}_{4}, \mathrm{CaCl}_{2}\right.$, and $\left.\mathrm{CaSO}_{4}\right]$ or products specifically formulated to deliver a low or negative DCAD.

Several trials and meta-analyses have been published demonstrating that DCAD is negatively correlated to blood and urinary pH (Sanchez et al., 1994; Hu and Murphy, 2004; Spanghero, 2004; Apper-Bossard et al., 2006; Charbonneau et al., 2006; Lean et al., 2006; Hu et al., 2007). Diets high in $\mathrm{Na}$ and $\mathrm{K}$ cause blood $\mathrm{pH}$ to increase, resulting in a state of mild metabolic acido- 
sis (Goff et al., 2004). This in turn reduces the ability of the periparturient cow to maintain Ca homeostasis at or near calving by reducing tissue responsiveness to parathyroid hormone (Phillippo et al., 1994; Goff and Horst, 1997b). Low DCAD diets $(\leq-5 \mathrm{mEq} / 100$ $\mathrm{g}$ of diet DM), achieved by addition of anions, increase target tissue responsiveness to parathyroid hormone by preventing mild metabolic alkalosis (Horst et al., 1997).

Several studies have shown improved Ca metabolism by decreasing DCAD through feeding anionic salts (Joyce et al., 1997; Moore et al., 2000). In these studies, the decline in blood $\mathrm{Ca}$ in the periparturient period of $\pm 2 \mathrm{~d}$ of calving was investigated. However, only one study (Block, 1984) has shown a positive milk yield response $(7 \%)$ for cows fed anionic salts prepartum. In addition, anionic salts can have a negative effect on prepartum DMI (Joyce et al., 1997; Moore et al., 2000). The reduction in prepartum DMI caused by the addition of anions is often attributed to decreased palatability, but may represent a response to metabolic acidosis induced by anionic salts (Vagnoni and Oetzel, 1998). Regardless of the exact mechanism by which anionic diets elicit their negative effect on prepartum DMI, decreasing DMI may have an adverse effect on metabolism.

The present study was conducted to determine if prepartum DCAD $(+20$ or $-10 \mathrm{mEq} / 100 \mathrm{~g}$ of $\mathrm{DM})$ and source of anions (feed-grade anionic salts or commercially available feedstuffs formulated to deliver negative DCAD) affect peripartum DMI, Ca homeostasis, and milk production in the subsequent lactation.

\section{MATERIALS AND METHODS}

\section{Animals and Diets}

The Oregon State University Institutional Animal Care and Use Committee approved all procedures involving animals. Thirty-five multiparous and 19 primiparous Holstein cows were selected from the Oregon State University Dairy Center, blocked by expected calving date, parity, and previous 305-d mature-equivalent production for cows. Animals within blocks were assigned at random to 1 of 4 prepartum dietary treatments beginning 4 wk before expected calving date. The experiment was a randomized incomplete block design. Main effects were parity and prepartum diet. Data were collected beginning $21 \mathrm{~d}$ prepartum and ending 21 $\mathrm{d}$ postpartum. Cows were group housed in a freestall barn and fed individually using Calan gates (American Calan, Northwood, NH).

Prepartum diets differed in DCAD, defined as milliequivalents of $[(\mathrm{Na}+\mathrm{K})-(\mathrm{Cl}+\mathrm{S})]$, and anionic sup- plement (Bio-Chlor and Fermenten; Church \& Dwight Co. Inc., Princeton, NJ), or feed-grade anionic salts. Dietary treatments were control (DCAD +20 mEq/100 $\mathrm{g}$ of DM; $\mathrm{n}=9$ cows and $\mathrm{n}=4$ heifers); Bio-Chlor (DCAD $-10 \mathrm{mEq} / 100 \mathrm{~g}$ of $\mathrm{DM} ; \mathrm{n}=9$ cows and $\mathrm{n}=$ 5 heifers); Fermenten (DCAD $-10 \mathrm{mEq} / 100 \mathrm{~g}$ of DM; $\mathrm{n}=8$ cows and $\mathrm{n}=5$ heifers); and salts (DCAD -10 $\mathrm{mEq} / 100 \mathrm{~g}$ of DM; $\mathrm{n}=9$ cows and $\mathrm{n}=5$ heifers.

Ingredients were sampled weekly, dried to static weight at $55^{\circ} \mathrm{C}$ in a forced-air oven, and ground through a 1-mm screen in a Thomas Wiley mill (Thomas Scientific, Philadelphia, PA). Weekly ingredient samples were composited monthly and analyzed by Cumberland Valley Analytical Services Inc. (Maugansville, MD). Nutrient composition of forages, concentrates, and mineral/vitamin premixes are shown in Tables 1, 2, and 3, respectively. Prepartum and postpartum diets were formulated using the CPM Dairy (version 3.0.10; www.CPMDairy.net) ration evaluator. Ingredient and nutrient composition of diets is shown in Tables 4 and 5 , respectively. Prepartum diets were formulated to be isonitrogenous and contained approximately 1.60 Mcal of $\mathrm{NE}_{\mathrm{L}} / \mathrm{kg}$ of DM. For prepartum diets, forages and concentrates were weighed and blended in a Uebler Mixing Cart (Uebler Manufacturing, Vernon, NY). Anionic supplementation was discontinued at calving. All cows received a common TMR postpartum that was mixed and delivered by the Oregon State University Dairy staff. Postpartum diet was formulated for approximately $17 \% \mathrm{CP}$ and $1.79 \mathrm{Mcal}$ of $\mathrm{NE}_{\mathrm{L}} / \mathrm{kg}$ of $\mathrm{DM}$. Cows were fed twice daily, with approximately 67 and $33 \%$ of daily feed allowance offered at 0700 and 1300 h, respectively. Feed offered and refused was recorded daily at the morning feeding.

\section{Plasma and Milk Sampling and Analysis}

Plasma samples were collected by venipuncture on $-21,-14,-11,-9,-7,-5,-3,-2,-1,0,1,7,14$, and $21 \mathrm{~d}$ relative to predicted parturition. Samples taken on $0 \mathrm{~d}$ were within $2 \mathrm{~h}$ of parturition, and $\mathrm{d} 1$ samples were taken $24 \mathrm{~h}$ after parturition. Blood was collected in tubes (Becton Dickinson, Franklin Lanes, NJ) containing K-EDTA, sodium heparin, or sodium heparin plus $\mathrm{NaF}$ and placed on ice immediately after collection. Plasma was separated after centrifugation at $1,600 \times g$ for $15 \mathrm{~min}$ at $5^{\circ} \mathrm{C}$, and frozen at $-80^{\circ} \mathrm{C}$ until analysis. Sampling time (approximately $1300 \mathrm{~h}$ ) corresponded to approximately $5 \mathrm{~h}$ after morning feeding.

Plasma samples were used for analysis of BHBA, NEFA, total Ca, glucose, $\mathrm{P}$, and cortisol. Plasma collected in tubes containing K-EDTA was analyzed for BHBA (procedure no. 2440, Stanbio Laboratory, Boerne, TX) and NEFA (NEFA-C, Wako Pure Chemi- 
Table 1. Chemical composition of forages (DM basis)

\begin{tabular}{|c|c|c|c|c|}
\hline Item & $\begin{array}{c}\text { Corn } \\
\text { silage }\end{array}$ & $\begin{array}{c}\text { Alfalfa } \\
\text { hay }\end{array}$ & $\begin{array}{l}\text { Oat } \\
\text { hay }\end{array}$ & $\begin{array}{l}\text { Grass } \\
\text { silage }\end{array}$ \\
\hline $\mathrm{CP}(\%)$ & 8.54 & 21.5 & 6.79 & 9.76 \\
\hline $\operatorname{ADICP}^{1}(\%)$ & 0.96 & 1.20 & 0.93 & 1.02 \\
\hline $\mathrm{NDICP}^{2}(\%)$ & 1.52 & 2.12 & 1.61 & 1.70 \\
\hline Soluble protein $(\%)$ & 4.35 & 8.72 & 1.95 & 5.70 \\
\hline $\mathrm{NE}_{\mathrm{L}}^{3}(\mathrm{Mcal} / \mathrm{kg})$ & 1.58 & 1.33 & 1.30 & 1.36 \\
\hline $\mathrm{NDF}(\%)$ & 43.6 & 34.2 & 57.7 & 54.7 \\
\hline $\operatorname{ADF}(\%)$ & 27.2 & 27.8 & 37.5 & 35.9 \\
\hline NFC $(\%)$ & 39.6 & 30.2 & 25.5 & 23.9 \\
\hline Crude fat $(\%)$ & 3.28 & 2.22 & 2.20 & 3.13 \\
\hline $\operatorname{Lignin}(\%)$ & 3.13 & 5.8 & 4.44 & 3.94 \\
\hline $\mathrm{Ca}(\%)$ & 0.23 & 1.43 & 0.28 & 0.37 \\
\hline $\mathrm{P}(\%)$ & 0.20 & 0.29 & 0.19 & 0.29 \\
\hline $\mathrm{Mg}(\%)$ & 0.19 & 0.38 & 0.12 & 0.17 \\
\hline $\mathrm{K}(\%)$ & 1.06 & 3.23 & 1.86 & 2.43 \\
\hline $\mathrm{Na}(\%)$ & 0.02 & 0.20 & 0.11 & 0.08 \\
\hline $\mathrm{S}(\%)$ & 0.13 & 0.32 & 0.13 & 0.18 \\
\hline $\mathrm{Cl}(\%)$ & 0.31 & 0.64 & 0.50 & 0.59 \\
\hline $\mathrm{Fe}(\mathrm{mg} / \mathrm{kg})$ & 321 & 626 & 143 & 825 \\
\hline Zn (mg/kg) & 36.5 & 18.4 & 25.7 & 37.9 \\
\hline $\mathrm{Cu}(\mathrm{mg} / \mathrm{kg})$ & 6.27 & 9.08 & 4.27 & 9.67 \\
\hline $\mathrm{Mn}(\mathrm{mg} / \mathrm{kg})$ & 49.8 & 53.0 & 67.2 & 149 \\
\hline $\operatorname{DCAD}^{4}(\mathrm{mEq} / 100 \mathrm{~g})$ & 11.2 & 53.4 & 30.2 & 37.8 \\
\hline
\end{tabular}

${ }^{1}$ Acid detergent insoluble CP.

${ }^{2}$ Neutral detergent insoluble CP.

${ }^{3}$ Calculated using the equation of Weiss et al. (1992).

${ }^{4} \mathrm{DCAD}=(\mathrm{Na}+\mathrm{K})-(\mathrm{Cl}+\mathrm{S})$.

Table 2. Chemical composition of concentrates (DM basis)

\begin{tabular}{|c|c|c|c|c|c|c|c|}
\hline Item & Corn/barley ${ }^{1}$ & $\mathrm{SBM} / \mathrm{DDG}^{1}$ & $\mathrm{DDG}^{2}$ & $\mathrm{WCS}^{3}$ & Bio-Chlor ${ }^{4}$ & Fermenten ${ }^{4}$ & $\begin{array}{l}\text { Protein } \\
\text { mix }\end{array}$ \\
\hline $\mathrm{CP}(\%)$ & 10.3 & 41.2 & 30.1 & 24.6 & 49.1 & 52.5 & 48.8 \\
\hline $\mathrm{ADICP}^{5}(\%)$ & 1.06 & 4.29 & 4.65 & 1.75 & 0.63 & 0.57 & 1.81 \\
\hline Soluble protein $(\%)$ & 1.47 & 6.63 & 4.74 & 5.73 & 38.3 & 39.9 & 33.1 \\
\hline $\mathrm{NE}_{\mathrm{L}}^{7}(\mathrm{Mcal} / \mathrm{kg})$ & 2.07 & 1.91 & 2.00 & 2.09 & 1.70 & 1.84 & 1.85 \\
\hline $\mathrm{NDF}(\%)$ & 15.6 & 25.5 & 42.8 & 47.1 & 22.6 & 19.1 & 30.8 \\
\hline $\operatorname{Lignin}(\%)$ & 1.36 & 3.54 & 4.74 & 11.5 & 2.33 & 1.78 & 3.29 \\
\hline $\mathrm{Ca}(\%)$ & 0.04 & 0.32 & 0.57 & 0.16 & 0.17 & 0.13 & 0.18 \\
\hline $\mathrm{P}(\%)$ & 0.30 & 0.80 & 0.86 & 0.76 & 0.73 & 0.70 & 0.74 \\
\hline $\operatorname{Mg}(\%)$ & 0.12 & 0.37 & 0.41 & 0.43 & 0.30 & 0.28 & 0.34 \\
\hline K $(\%)$ & 0.43 & 1.75 & 1.10 & 1.23 & 1.11 & 1.04 & 1.01 \\
\hline $\mathrm{Na}(\%)$ & 0.02 & 0.52 & 0.61 & 0.05 & 1.15 & 0.30 & 0.07 \\
\hline $\mathrm{Mn}(\mathrm{mg} / \mathrm{kg})$ & 12.2 & 41.3 & 73.9 & 20.1 & 79.1 & 96.2 & 74.5 \\
\hline $\operatorname{DCAD}^{8}(\mathrm{mEq} / 100 \mathrm{~g})$ & -0.24 & 52.1 & -7.21 & 13.4 & -319 & -410 & 2.73 \\
\hline
\end{tabular}

${ }^{1}$ Rolled corn/barley and soybean meal/dried distillers grain, 1:1 ratio on an as-fed basis.

${ }^{2}$ Dried distillers grain.

${ }^{3}$ Whole cotton seed.

${ }^{4}$ From Church \& Dwight Inc. (Princeton, NJ).

${ }^{5}$ Acid detergent insoluble CP.

${ }^{6}$ Neutral detergent insoluble CP.

${ }^{7}$ Calculated using the equation of Weiss et al. (1992).

${ }^{8} \mathrm{DCAD}=(\mathrm{Na}+\mathrm{K})-(\mathrm{Cl}+\mathrm{S})$. 
Table 3. Chemical composition of vitamin and mineral mixes (DM basis)

\begin{tabular}{|c|c|c|c|c|c|}
\hline Item & \multicolumn{4}{|c|}{ Prepartum } & Postpartum \\
\hline $\mathrm{Ca}(\%)$ & 19.8 & 19.8 & 20.0 & 18.3 & 9.93 \\
\hline $\operatorname{Mg}(\%)$ & 0.49 & 0.16 & 0.50 & 0.45 & 1.99 \\
\hline $\mathrm{K}(\%)$ & 1.75 & 0.23 & 1.60 & 1.56 & 1.54 \\
\hline $\mathrm{S}(\%)$ & 0.24 & 0.23 & 0.34 & 5.90 & 0.99 \\
\hline $\mathrm{Co}(\mathrm{mg} / \mathrm{kg})$ & 1.65 & 3.30 & 1.65 & 1.65 & 3.97 \\
\hline $\mathrm{Cu}(\mathrm{mg} / \mathrm{kg})$ & 393 & 720 & 730 & 645 & 397 \\
\hline $\mathrm{Fe}(\mathrm{mg} / \mathrm{kg})$ & 3,044 & 2,625 & 3,039 & 2,800 & 0 \\
\hline $\mathrm{Mn}(\mathrm{mg} / \mathrm{kg})$ & 180 & 300 & 180 & 201 & 1,589 \\
\hline $\mathrm{Zn}(\mathrm{mg} / \mathrm{kg})$ & 695 & 702 & 745 & 636 & 1,589 \\
\hline $\mathrm{Se}(\mathrm{mg} / \mathrm{kg})$ & 6.00 & 7.00 & 6.80 & 5.60 & 11.9 \\
\hline Vitamin A (kIU/kg) & 185 & 185 & 185 & 170 & 127 \\
\hline
\end{tabular}

${ }^{1}$ From Church \& Dwight Inc. (Princeton, NJ).

${ }^{2} \mathrm{DCAD}=(\mathrm{Na}+\mathrm{K})-(\mathrm{Cl}+\mathrm{S})$.

cal Industries, Richmond, VA). Plasma in tubes containing $\mathrm{Na}$ heparin plus $\mathrm{NaF}$ was analyzed for glucose (procedure no. 1070, Stanbio Laboratory). Plasma in tubes containing $\mathrm{Na}$ heparin was analyzed for total Ca (procedure no. 0150, Stanbio Laboratory), P (procedure no. 0830; Stanbio Laboratory), and cortisol (DSL10-2000, Diagnostic Systems Laboratories, Oxon, UK). All spectrophotometric measurements were conducted using a Bio-Tek (Winooski, VT) EL-309 microplate autoreader.
Liver samples were obtained by percutaneous trochar biopsy (Veenhuizen et al., 1991) from each cow at $-21 \mathrm{~d}$ prepartum, within $2 \mathrm{~d}$ postpartum, and at $21 \mathrm{~d}$ postpartum, and were immediately frozen and stored at $-80^{\circ} \mathrm{C}$ until analysis. Liver biopsies were performed at approximately $1330 \mathrm{~h}$ and were approximately $3 \mathrm{~g}$. Based on observations, liver biopsy did not result in decreased milk production or feed intake. Liver triglyceride content was determined using the procedure de-

Table 4. Ingredient composition of diets (DM basis)

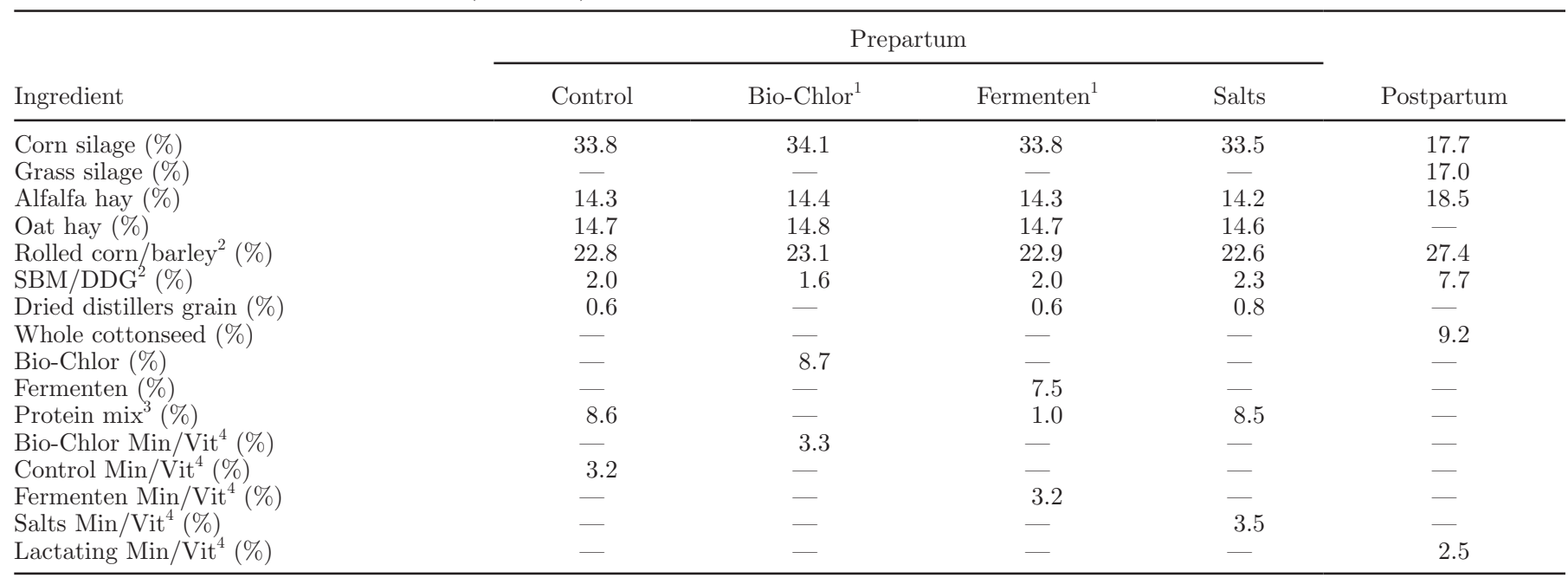

${ }^{1}$ From Church \& Dwight Inc. (Princeton, NJ).

${ }^{2}$ Rolled corn/barley and soybean meal/dried distillers grain, 1:1 ratio on an as-fed basis.

${ }^{3}$ Contains $9.3 \%$ ground corn, $54.7 \%$ wheat middlings, $21.5 \%$ dried distillers grain, $4.8 \%$ SBM, and $9.7 \%$ urea on a DM basis.

${ }^{4} \mathrm{Mineral} /$ vitamin mixes were prepared from feed-grade mineral sources; the chemical composition of all mixes is shown in Table 3 . 
Table 5. Chemical composition of diets (DM basis)

\begin{tabular}{|c|c|c|c|c|c|}
\hline Item & \multicolumn{4}{|c|}{ Prepartum } & Postpartum \\
\hline CP (\%) & 14.7 & 14.7 & 14.9 & 14.7 & 15.5 \\
\hline $\mathrm{NE}_{\mathrm{L}}^{2}(\mathrm{Mcal} / \mathrm{kg})$ & 1.61 & 1.59 & 1.59 & 1.59 & 1.59 \\
\hline $\operatorname{NDF}(\%)$ & 35.7 & 35.0 & 34.6 & 35.6 & 34.0 \\
\hline NFC $(\%)$ & 39.7 & 40.3 & 39.8 & 39.5 & 38.3 \\
\hline $\operatorname{Mg}(\%)$ & 0.22 & 0.20 & 0.21 & 0.22 & 0.28 \\
\hline $\mathrm{K}(\%)$ & 1.38 & 1.34 & 1.37 & 1.37 & 1.60 \\
\hline $\mathrm{Na}(\%)$ & 0.19 & 0.16 & 0.18 & 0.19 & 0.30 \\
\hline S (\%) & 0.20 & 0.38 & 0.71 & 0.40 & 0.25 \\
\hline $\mathrm{Cl}(\%)$ & 0.32 & 1.05 & 0.35 & 1.00 & 0.33 \\
\hline $\mathrm{Fe}(\mathrm{mg} / \mathrm{kg})$ & 341 & 329 & 341 & 341 & 347 \\
\hline
\end{tabular}

${ }^{1}$ Both from Church \& Dwight Inc. (Princeton, NJ).

${ }^{2}$ Calculated using the equation of Weiss et al. (1992).

${ }^{3} \mathrm{DCAD}=(\mathrm{Na}+\mathrm{K})-(\mathrm{Cl}+\mathrm{S})$.

scribed by Piepenbrink et al. (2004) and a commercial kit (procedure no. 2200; Stanbio Laboratory).

Milk was weighed at each of 2 milkings per day. At the end of each 7-d period postpartum, milk was sampled for fat, protein, and SCC analysis by Willamette Valley DHIA (Salem, OR). The 2 daily samples were proportionately composited to obtain a single analysis per cow each $7 \mathrm{~d}$.

Body weight and BCS were measured weekly. Body condition score was assigned using a 5 -point scale $(1=$ thin, 5 = fat; Wildman et al., 1982) by 2 individuals. Midstream urine samples were obtained at the time of blood sampling by manual stimulation of the vulva and analyzed for $\mathrm{pH}$ immediately after collection with a pH meter (Corning model $20 \mathrm{pH}$ meter; Corning Life Sciences, Acton, MA). Energy balance was calculated for all cows using BW and NRC (2001) equations for $\mathrm{NE}_{\mathrm{L}}$ requirement.

\section{Statistical Analysis}

Data were analyzed as repeated measures using the Proc Mixed procedure in SAS (SAS Institute, 2001). Cow within block by parity by treatment was defined as the subject. For equally spaced repeated measures, a first-order autoregressive covariance structure was used. Akaike's information criterion was used to select the best covariance structure from 1 of 3 spatial structures [SP(POW) (spatial power law), SP(GAU) (Gaussian), and $\mathrm{SP}(\mathrm{SPH})$ (spherical)] for unequally spaced repeated measures. Prepartum and postpartum data were analyzed separately. For all variables, cows and heifers were analyzed together to test parity and parity by diet interactions (Moore et al., 2000). The model used was

$$
\begin{gathered}
\mathrm{Y}_{\mathrm{ijklm}}=\mu \\
+\mathrm{B}_{\mathrm{i}}+\mathrm{P}_{\mathrm{j}}+\mathrm{T}_{\mathrm{k}}+\mathrm{PT}_{\mathrm{jk}}+\mathrm{C}_{(\mathrm{ijk}) \mathrm{l}} \\
+\mathrm{D}_{\mathrm{m}}+\mathrm{DP}_{\mathrm{jm}}+\mathrm{e}_{\mathrm{ijklm}},
\end{gathered}
$$

where $\mathrm{Y}_{\mathrm{ijklm}}=$ dependent variable; $\mu=$ overall mean; $\mathrm{B}_{\mathrm{i}}=$ ith block $(1,2, \ldots 9) ; \mathrm{P}_{\mathrm{j}}=$ jth parity; $\mathrm{T}_{\mathrm{k}}=\mathrm{kth}$ treatment (control, Bio-Chlor, Fermenten, and salts); $\mathrm{C}_{(\mathrm{ijk}) \mathrm{l}}=$ lth cow within the ith block, the jth parity, and the kth treatment; $\mathrm{D}_{\mathrm{m}}=\mathrm{mth}$ day or week (repeated measure); and e = residual error.

Urine $\mathrm{pH}$, prepartum and postpartum cortisol, and prepartum and postpartum Ca were significant for parity by prepartum diet interactions. All other data were then analyzed separately to view diet effects (Moore et al., 2000). All other results will be shown separately for cows and heifers. Results in tables are reported as least squares means. Preplanned contrasts were control versus all anionic supplements and Bio-Chlor versus anionic salts. Data for DMI and production by day were compared by orthogonal contrasts: linear, quadratic, and cubic. Significance was declared at $P \leq 0.05$ and trends at $0.05<P \leq 0.10$.

\section{RESULTS AND DISCUSSION}

Nutrient and ingredient composition and analyses are in Tables 1 through 5. Because of the variability 
Table 6. Effect of prepartum diet and parity on BW, BCS, and urine pH

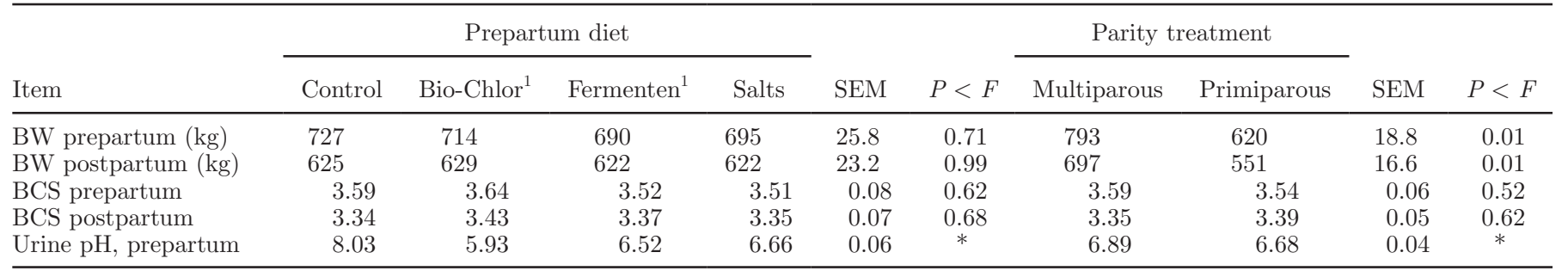

${ }^{1}$ Both from Church \& Dwight Inc. (Princeton, NJ).

*Parity by treatment interaction $(P<0.05)$.

of ingredient mineral composition, average DCAD was $+22,-12,-11$, and $-10 \mathrm{mEq} / 100 \mathrm{~g}$ of $\mathrm{DM}$ for control, Bio-Chlor, Fermenten, and salts diets, respectively (Table 5). It is noteworthy that the Fermenten diet was higher in S, at $0.71 \%$ of DM, than NRC (2001) suggests as the maximum tolerable amount of dietary $\mathrm{S}$ at $0.4 \%$ of DM. None of the negative effects associated with excess feeding of S (NRC, 2001) were observed in cows, likely because of the short period (21 d) over which this high amount of $\mathrm{S}$ was fed.

The average number of lactations for multiparous cows was 2.78, 2.89, 3.00, and 3.11 for control, BioChlor, Fermenten, and salts diets respectively. Average number of days cows were on prepartum diet were 29, 31,29 , and 30 for all cows on the control, Bio-Chlor, Fermenten, and anionic salts diets, respectively. Seven cows did not finish the trial: 3 on the Bio-Chlor diet (displaced abomasum, stillborn twins, and intestinal blockage); 2 on the control diet (displaced abomasum and $18 \mathrm{~d}$ overdue); and 2 on the Fermenten diet (underconditioned and lameness). These cows were removed from the trial at or soon after calving. Data from these 7 cows were not included in analysis, and animals were replaced with other cows. Cows not on treatment for at least $14 \mathrm{~d}$ before parturition were also excluded from the data set and replaced as soon as possible. Four cows had twins ( 2 on control, 1 on Fermenten, and 1 cow on anionic salts), and were included in the data set because these cows responded similarly to the treatments compared with cows that had a single birth.

\section{$B W, B C S$, and Urine $p H$}

Diet and parity means for BW, BCS, and urine $\mathrm{pH}$ are shown in Table 6 . Body weight was not different between prepartum diets $(P<0.71)$ during the prepartum period. As expected, prepartum and postpartum BW were greater for multiparous compared with primiparous cows. Body weight from wk 3 before parturition to wk 1 before parturition increased $(P<0.08)$ from 704 to $711 \mathrm{~kg}$, respectively, for primiparous and multiparous cows combined. Body weight during the postpartum period was similar $(P<0.99)$ between diets for all cows. Postpartum BW decreased $(P<0.01)$ from $644 \mathrm{~kg}$ in wk 1 to $606 \mathrm{~kg}$ by wk 3 for all cows.

Prepartum BCS was not different $(P<0.62)$ between animals fed the 4 diets, with an average BCS for all prepartum cows at 3.56 . Body condition score during the postpartum period was similar between cows fed prepartum diets $(P=0.68)$ and parity $(P=0.62)$. Average BCS across all cows decreased $(P<0.01)$ from 3.44 in wk 1 to 3.30 by wk 3 postpartum.

Parity by diet interaction was significant $(P<0.01)$ for urine $\mathrm{pH}$. Primiparous cows receiving Fermenten had lower urine $\mathrm{pH}$ values compared with multiparous cows fed Fermenten (6.24 vs. $6.80 ; P<0.01$ ). Likewise, primiparous cows fed salts tended to have lower urine $\mathrm{pH}$ values compared with multiparous cows receiving salts $(6.55$ vs. $6.77 ; P<0.08)$. Anionic diets were effective in reducing urine $\mathrm{pH}$ below the 6.5 threshold recommended for Holsteins (Moore et al., 2000). All negative DCAD diets produced lower $(P<0.01)$ urine $\mathrm{pH}$ values, with an average value of 6.37 compared with control cows with a value of 8.03.

\section{DMI, Milk Yield and Composition, and Energy Balance}

Prepartum means for DMI, milk production and composition, and energy balance are shown in Table 7. Prepartum diet did not affect prepartum DMI of cows or heifers. Horst et al. (1994) first suggested that addition of $>300 \mathrm{mEq}$ of anions $/ \mathrm{kg}$ of diet might reduce intake. In a meta-analysis, Charbonneau et al. (2006) showed that reducing DCAD by $300 \mathrm{mEq} / \mathrm{kg}$ substantially reduced DMI in prepartum transition cows. The Bio-Chlor, Fermenten, and salts diets were supplemented with 275,312 , and $257 \mathrm{mEq}$ anions $/ \mathrm{kg}$ of DM, respectively. Therefore, anionic supplementation in the current experiment was near or below the threshold at which DMI would be negatively affected. Joyce et al. (1997) reported depressed DMI in multipa- 
Table 7. Effect of prepartum diet and parity on DMI, milk yield and composition, and energy balance (EB) ${ }^{1}$

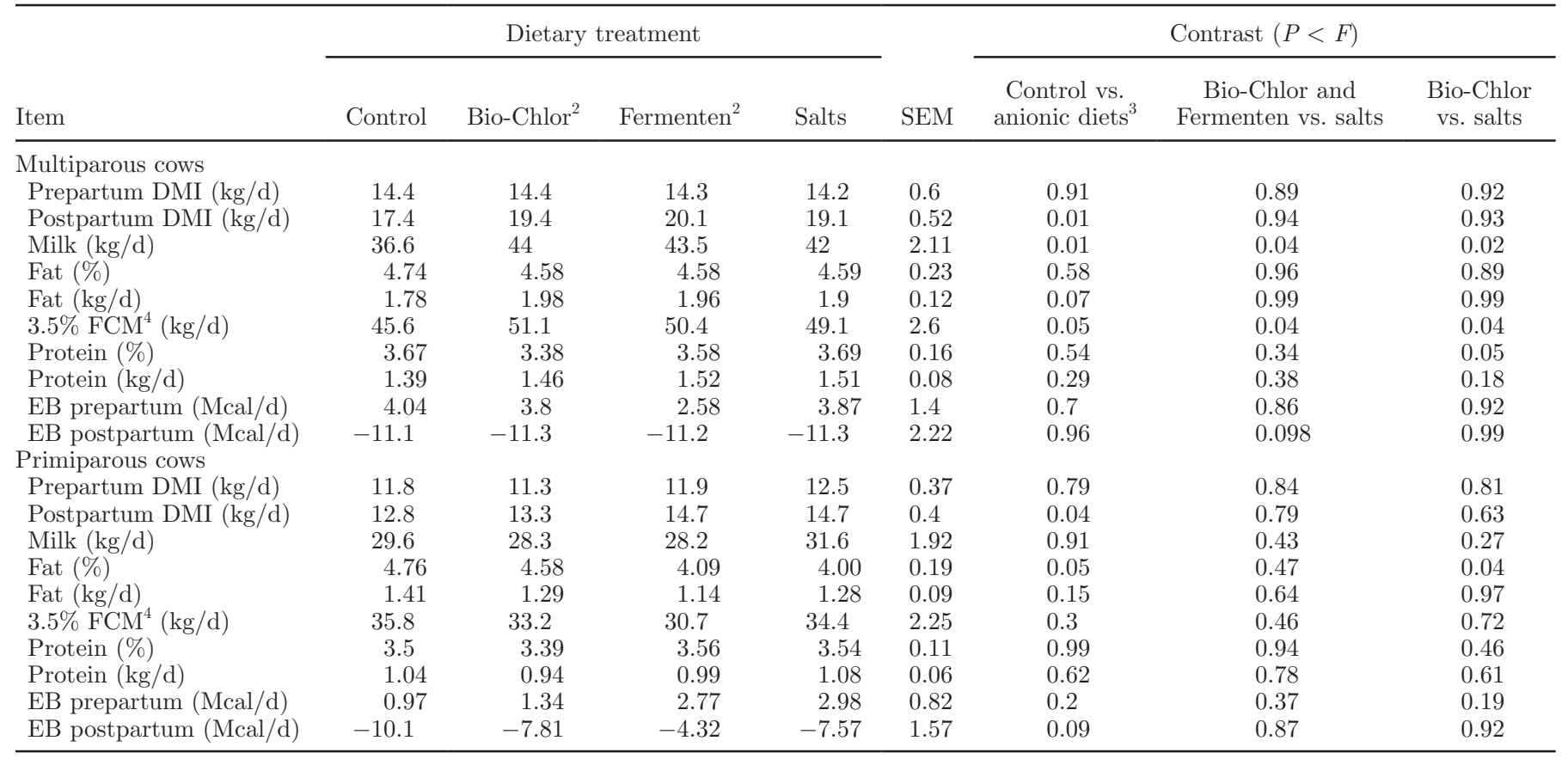

${ }^{1}$ Results shown are least squares means from separate analyses for cows and heifers. In an analysis of both cows and heifers, cows were different $(P<0.01)$ from heifers for all variables except percentage of milk fat and protein, and prepartum energy balance.

${ }^{2}$ Both from Church \& Dwight Inc. (Princeton, NJ).

${ }^{3}$ Control versus anionic treatments (Bio-Chlor, Fermenten, salts).

${ }^{4} 3.5 \% \mathrm{FCM}=0.4324 \times(\mathrm{kg}$ milk $)+16.2162 \times(\mathrm{kg}$ fat $)$.

rous cows supplemented with $471 \mathrm{mEq}$ anions $/ \mathrm{kg}$ of DM, whereas Moore et al. (2000) showed no decline in DMI for multiparous cows supplemented with $329 \mathrm{mEq}$ anions/kg of DM; however, prepartum DMI was lower for heifers supplemented with $329 \mathrm{mEq}$ anions/ $\mathrm{kg}$ of DM. Prepartum DMI differed by day $(P<0.01)$ for all cows, decreasing linearly and quadratically from 14.5 to $9.9 \mathrm{~kg}$ from $-21 \mathrm{~d}$ to $-1 \mathrm{~d}$ prepartum, respectively. Parities differed $(P<0.01)$ during the prepartum period, with cows consuming $14.2 \mathrm{~kg}$ of DM/d and heifers consuming $11.9 \mathrm{~kg}$ of DM/d. Prepartum DMI of heifers was similar to that in a data set compiled by Hayirli et al. (2002); however, cows in that experiment consumed $1.85 \mathrm{~kg}$ of $\mathrm{DM} / \mathrm{d}$ less on average than the cows in the current study. Parity by day or prepartum diet by day interactions were not significant for prepartum DMI.

Dry matter intake during the postpartum period was significantly affected by parity and prepartum diet. Multiparous cows fed an anionic prepartum diet had greater DMI postpartum compared with cows fed the control diet (19.5 vs. $17.4 \mathrm{~kg}$ of $\mathrm{DM} / \mathrm{d} ; P<0.01)$. Likewise, postpartum DMI was greater for primiparous cows fed an anionic prepartum diet compared with control cows (14.2 vs. $12.8 \mathrm{~kg}$ of $\mathrm{DM} / \mathrm{d} ; P<0.04)$. Others have shown that feeding an anionic diet prepartum does not decrease postpartum DMI (Goff and Horst, 1998; Gulay et al., 2004) or increases postpartum DMI (Joyce et al., 1997). As expected, multiparous cows consumed more DM postpartum compared with primiparous cows (17.5 vs. $13.7 \mathrm{~kg}$ of $\mathrm{DM} / \mathrm{d} ; P<0.01$ ). Dry matter intake increased (linear, quadratic, cubic; $P<0.01$ ) for all cows, from $9.7 \mathrm{~kg}$ of $\mathrm{DM} / \mathrm{d}$ on the day of calving to $28.9 \mathrm{~kg}$ of $\mathrm{DM} / \mathrm{d}$. Parity by day or prepartum diet by day interactions were not significant for postpartum DMI. It is possible that herds with excellent feeding practices, reflected by consistently high DMI, do not experience a depression in DMI when low DCAD diets are fed.

Milk production was greater for multiparous cows fed anionic prepartum diets versus control diets (43.1 vs. $36.6 \mathrm{~kg} / \mathrm{d} ; P<0.01)$. Production of $3.5 \% \mathrm{FCM}$ was significantly greater for multiparous cows fed anionic prepartum diets versus control diets (50.2 vs. $45.6 \mathrm{~kg} / \mathrm{d} ; P<0.05)$. These increases were attributed to the significant increase in DMI during the postpartum period for anionic prepartum diets versus control. Within the anionic treatments, the multiparous cows fed Bio-Chlor and Fermenten prepartum produced more milk $(P<0.05)$ postpartum than the cows fed anionic salts. Prepartum diet did not affect milk pro- 


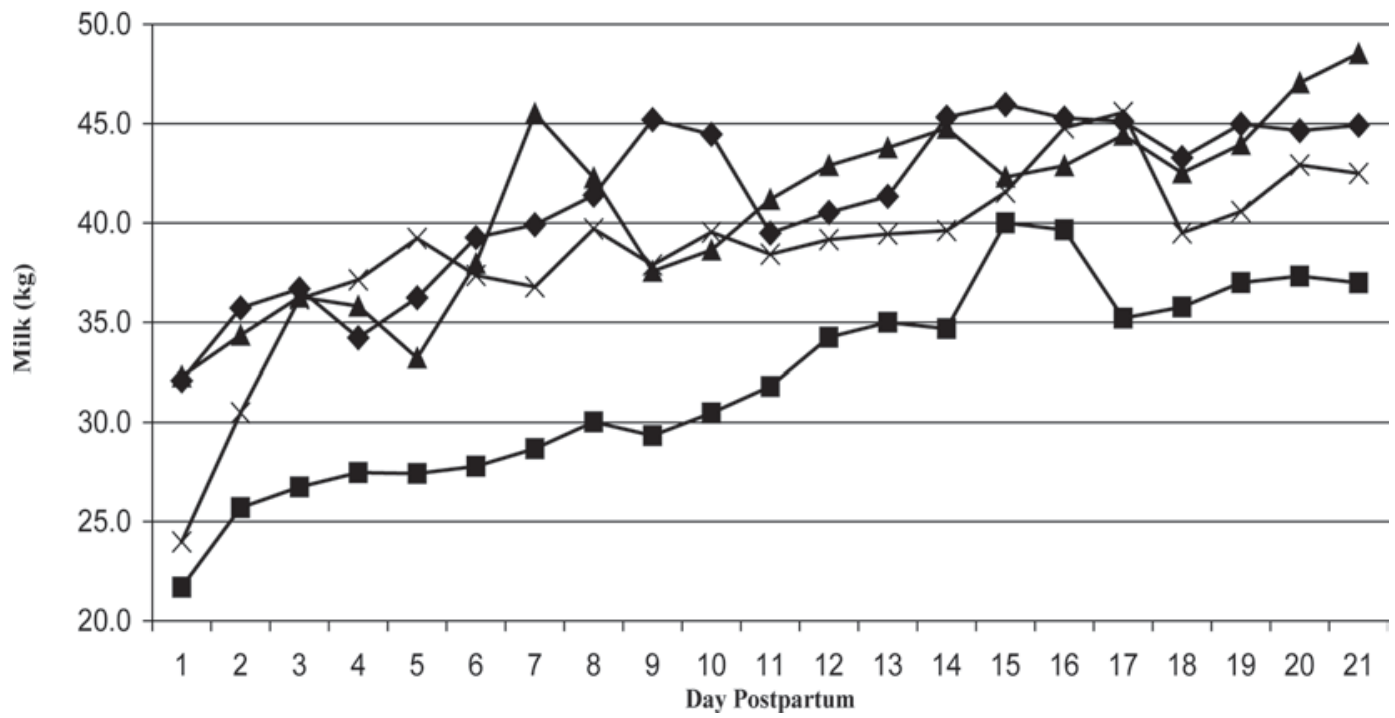

Figure 1. Temporal pattern of milk produced $(\mathrm{kg} / \mathrm{cow}$ per day) by multiparous cows for the first $21 \mathrm{~d}$ postpartum when fed prepartum transition diets that had a positive DCAD (control $\mathbf{a}$; mean $=32 \mathrm{~kg} /$ cow per day), a negative DCAD with anionic salts $(\times$; mean $=38.7 \mathrm{~kg} /$ cow per day), a negative DCAD with Bio-Chlor $(\bullet$ mean $=41.2 \mathrm{~kg} /$ cow per day), or a negative DCAD with Fermenten $(\mathbf{\Delta} ;$ mean $=40.9 \mathrm{~kg} /$ cow per day). Bio-Chlor and Fermenten were from Church \& Dwight Inc. (Princeton, NJ).

duction of primiparous cows $(29.4 \mathrm{~kg} / \mathrm{d} ; P<0.91)$. Parity by day interaction was significant $(P<0.01)$ for milk production, with multiparous cows increasing at a faster rate compared with primiparous cows (data not shown). Prepartum diet by day interaction was not significant for milk production. Primiparous cows fed the anionic diets exhibited increased DMI $(P<0.05)$ and tended to have less of a negative energy balance postpartum $(P<0.10$; Table 7$)$. These animals were probably partitioning more nutrients to growth than the multiparous cows, thereby explaining the lack of a milk production response. The least squares means for milk production from all cows fed control compared with anionic diets were 33.7 versus $38.3 \mathrm{~kg} /$ cow day, respectively $(P<0.05)$.

Milk fat and milk protein percentages and yields were similar for all diets in multiparous and primiparous cows. Primiparous cows fed anionic diets prepartum tended $(P<0.06)$ to have a lower fat percentage compared with heifers fed the control diet prepartum. Fat percentage decreased $(P<0.01)$ for all cows by week, from $4.95 \%$ in wk 1 postpartum to $4.20 \%$ in wk 3. Likewise, protein percentage decreased $(P<0.01)$ by week for all cows, from $4.07 \%$ in wk 1 postpartum to $3.11 \%$ in wk 3 postpartum. Butterfat yield increased $(P<0.01)$ by week for multiparous cows, from 1.83 to $1.98 \mathrm{~kg} / \mathrm{d}$ from wk 1 to wk 3 postpartum. No difference $(P<0.76)$ by week in butterfat yield was observed for primiparous cows. Protein yield did not differ $(P$ $<0.43$ ) by week for primiparous or multiparous cows; $3.5 \%$ FCM increased $(P<0.01)$ by week for multipa- rous cows from $45.2 \mathrm{~kg} / \mathrm{d}$ in wk 1 to $51.2 \mathrm{~kg} / \mathrm{d}$ in wk 3 postpartum. Prepartum diet by day interaction was not significant for $3.5 \% \mathrm{FCM}$, fat, or protein yields.

The temporal pattern of milk produced by multiparous cows is shown in Figure 1. Cows consuming the negative DCAD diets prepartum produced more milk compared with control cows for the full 21-d postpartum period. However, cows fed Bio-Chlor and Fermenten prepartum had greater average initial milk production that remained consistently higher compared with cows fed anionic salts for the 21-d postpartum period $(P<0.05$, Table 7$)$. Although the diets were isonitrogenous and isocaloric, the cows fed Bio-Chlor and Fermenten could have been in a better protein status because of the positive effects of these products on rumen microbial fermentative efficiency (Lean et al., 2005). The possibility exists that cows fed Bio-Chlor and Fermenten were in better protein status at calving, resulting in their higher milk production throughout the 21-d period postpartum (Huyler et al., 1999).

Energy balance was similar for all diets during the pre- and postpartum periods for multiparous cows. Energy balance was also similar for heifers during the prepartum period; however, energy balance for the postpartum period tended $(P<0.09)$ to be less negative for anionic diets versus the control diet. Parity by week interaction was significant $(P<0.01)$ for prepartum energy balance when cows and heifers were analyzed together (Figure 2). Multiparous cows started the trial in higher energy balance than primiparous cows; however, prepartum energy balance was similar 
Table 8. Effect of prepartum diet on pre- and postpartum glucose, P, BHBA, NEFA, and liver triacylglycerol (TAG) ${ }^{1}$

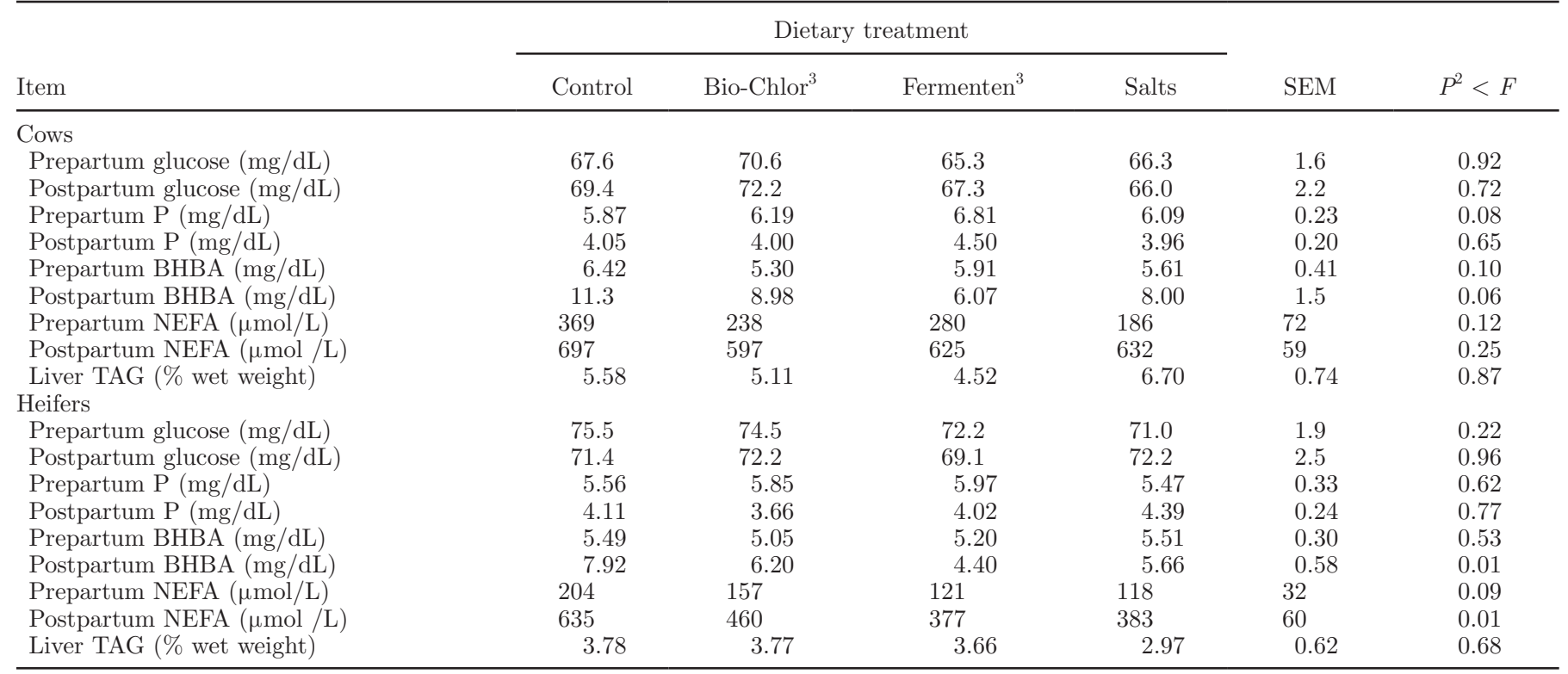

${ }^{1}$ Results shown are least squares means from separate analyses for cows and heifers. In an analysis of both cows and heifers, cows were different from heifers for all variables $(P<0.01)$ except prepartum and postpartum $\mathrm{P}$ and liver TAG.

${ }^{2}$ Control versus anionic treatments (Bio-Chlor, Fermenten, salts).

${ }^{3}$ Both from Church \& Dwight Inc. (Princeton, NJ).

by wk 2 prepartum. Parity by week or prepartum diet by week interactions were not significant for prepartum energy balance. However, parity by week interaction was significant $(P<0.03)$ for the postpartum period.

\section{Plasma Metabolites}

Prepartum diet means for plasma metabolites are shown in Table 8. Prepartum diet did not affect prepartum or postpartum plasma glucose. Prepartum plasma glucose concentrations were unaffected by prepartum diet, but were affected by day and parity. Plasma glucose concentrations during the prepartum period decreased as parturition approached, and then increased the day before calving $(P<0.01)$. Glucose concentrations prepartum were higher in heifers versus cows (73.4 vs. 67.4 $\mathrm{mg} / \mathrm{dL} ; P<0.01)$. Prepartum diet by day interaction was not significant for plasma glucose. Postpartum glucose concentrations differed for parity by day $(P<$ 0.01). Postpartum glucose concentrations decreased in multiparous cows, but not in primiparous cows.

Prepartum plasma $\mathrm{P}$ tended $(P<0.08)$ to be greater for multiparous cows fed an anionic diet prepartum. Prepartum plasma $\mathrm{P}$ concentrations were affected by day with concentrations decreasing from $21 \mathrm{~d}$ prepartum to $1 \mathrm{~d}$ before parturition $(6.6$ to $5.4 \mathrm{mg} / \mathrm{dL} ; P<$ 0.01). Prepartum and postpartum plasma $P$ levels were similar between parities. Postpartum $\mathrm{P}$ concentrations were affected by day $(P<0.01)$ with concentrations increasing from the day of calving to $21 \mathrm{~d}$ postpartum. Diet had no effect on postpartum $\mathrm{P}$ concentrations. Parity by day or prepartum diet by day interactions were not significant for prepartum and postpartum plasma $\mathrm{P}$ concentrations.

Prepartum BHBA concentrations were similar between heifers and cows. Prepartum diet did not affect

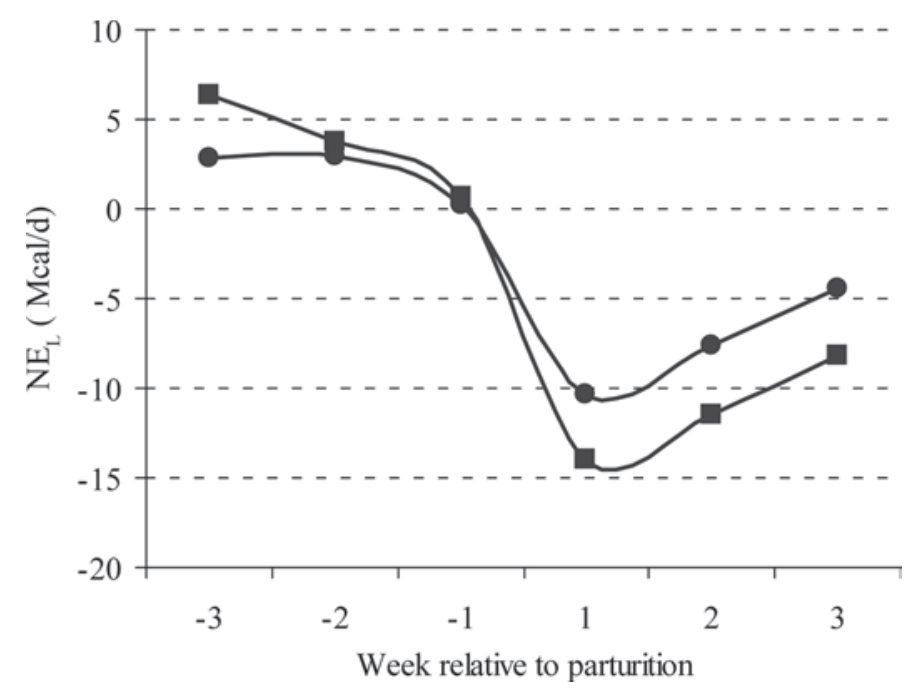

Figure 2. Energy balance of cows ( $)$ and heifers ( $)$ during the transition period. Prepartum and postpartum data were analyzed separately. Parity by week interaction was significant $(P<0.01)$ for prepartum period, as was parity $(P<0.05)$. 
prepartum BHBA concentrations. Prepartum BHBA increased $(P<0.01)$ from $21 \mathrm{~d}$ prepartum to $1 \mathrm{~d}$ prepartum for all cows. Postpartum BHBA was lower for both multiparous $(P<0.06)$ and primiparous $(P<$ 0.01 ) cows fed anionic diets prepartum compared with the control diet. Postpartum BHBA concentrations were affected by day $(P<0.01)$ for all cows, peaking at $\mathrm{d} 7$ postpartum and decreasing through $21 \mathrm{~d}$ postpartum. A parity difference in postpartum BHBA was observed, with cows having concentrations of 8.58 $\mathrm{mg} / \mathrm{dL}$ and heifers $5.39 \mathrm{mg} / \mathrm{dL}(P<0.02)$. Parity by day or prepartum diet by day interactions were not significant for prepartum and postpartum plasma BHBA concentrations.

Prepartum NEFA concentrations differed between parity $(268$ and $73 \mu \mathrm{mol} / \mathrm{L}$ for cows and heifers respectively; $P<0.01)$. Prepartum NEFA levels increased $(P<0.01)$ from 80 to $340 \mu \mathrm{mol} / \mathrm{L}$, from $21 \mathrm{~d}$ to 1 d prepartum, respectively. Prepartum diet had no effect on prepartum NEFA concentrations for cows. A trend $(P<0.09)$ was detected for heifers fed negative DCAD diets to have lower prepartum NEFA than heifers fed the control diet. A decrease in postpartum NEFA concentration was found for primiparous cows fed an anionic diet prepartum versus control diet $(P$ $<0.01$ ). Dry matter intake and NEFA concentrations have been shown to be inversely related during the postpartum period (Lean et al., 1992), which would explain the increase in postpartum DMI of primiparous cows fed anionic diets prepartum. Parity also affected postpartum NEFA levels with multiparous cows having greater $(P<0.01)$ concentrations $(638 \mu \mathrm{mol} / \mathrm{L})$ than primiparous cows $(360 \mu \mathrm{mol} / \mathrm{L})$ throughout the postpartum period. Postpartum NEFA levels decreased from the day of parturition to $21 \mathrm{~d}$ postpartum $(P<$ 0.01 ). Other studies have shown that NEFA concentrations begin increasing approximately $5 \mathrm{~d}$ before calving, peak at or around calving, and begin to decrease 3 to 5 d postpartum (Grummer, 1993; Goff et al., 1996). Results of the current research are in agreement with these recent studies. Parity by day or prepartum diet by day interactions were not significant for prepartum and postpartum plasma NEFA concentrations.

Liver triacylglycerol (TAG; \% wet weight) differed for parity by day $(P<0.03)$. Parities were similar at 21 d prepartum, but liver TAG was greater for multiparous cows the day of parturition (5.92 vs. $2.95 \%$ wet weight for multiparous and primiparous cows, respectively) and $21 \mathrm{~d}$ postpartum (7.94 vs. $3.58 \%$ wet weight for multiparous and primiparous cows, respectively). Liver TAG concentrations have been correlated with circulating NEFA concentrations (Grummer, 1993). For multiparous cows, greater plasma NEFA during both the prepartum and postpartum periods compared with primiparous cows lead to differences in liver TAG. Prepartum diet had no affect on liver TAG during the transition period. Prepartum diet by day interaction was not significant for the transition period.

Plasma Ca concentrations for the prepartum (11.0 vs. $9.2 \mathrm{mg} / \mathrm{dL}$ for primiparous and multiparous, respectively) and postpartum (11.3 vs. $8.7 \mathrm{mg} / \mathrm{dL}$ for primiparous and multiparous, respectively) periods were greater for primiparous cows versus multiparous cows $(P<0.01)$. Dietary treatment had no effect on average prepartum plasma Ca concentration for cows or heifers. Prepartum plasma Ca was not different by day for cows or heifers. Parity or diet by day interactions was not significant. An interaction $(P<0.01)$ between parity and prepartum diet was also shown during the postpartum period for plasma $\mathrm{Ca}$ concentrations. Concentrations of postpartum plasma $\mathrm{Ca}$ for primiparous cows were similar across prepartum diet. This interaction was due to the magnitude of the difference between primiparous and multiparous cows. Parity by day interaction was significant because of multiparous cows not acting similarly to primiparous cows during the postpartum period $(P<0.01)$. Plasma Ca concentrations for primiparous cows increased until 21 d postpartum where levels decreased. However, multiparous plasma Ca concentrations in cows postpartum increased from the day of parturition through $21 \mathrm{~d}$ postpartum. Prepartum diet by day interaction was not significant.

The use of anionic salts during the prepartum period has repeatedly been shown to prevent hypocalcemia in multiparous cows at or near calving (Block, 1984; Horst et al., 1997; Joyce et al., 1997). Our results are similar to those of Moore et al. (2000), which showed no improvement in postpartum Ca metabolism of primiparous cows when supplemented with an anionic diet prepartum. It is noteworthy that even in studies showing no significant differences in periparturient plasma $\mathrm{Ca}$ when feeding negative DCAD prepartum, all showed numerical increases in this statistic. The likely limitation in the present study, as well as others showing no significant improvement, was inadequate sample size used to evaluate the highly variable statistic of plasma Ca. The meta-analyses by Charbonneau et al. (2006) and Lean et al. (2006) showed that this statistic significantly improved when feeding negative DCAD prepartum.

The temporal pattern of concentration of calcium in plasma by day relative to calving is shown in Figure 3. Although no differences in average daily plasma calcium concentration were observed, Figure 3 suggests that cows fed the control diet began to decline in plasma calcium $5 \mathrm{~d}$ before parturition, whereas cows fed negative DCAD diets began to decline between $\mathrm{d}$ 1 prepartum and parturition. Only 2 cows had plasma 


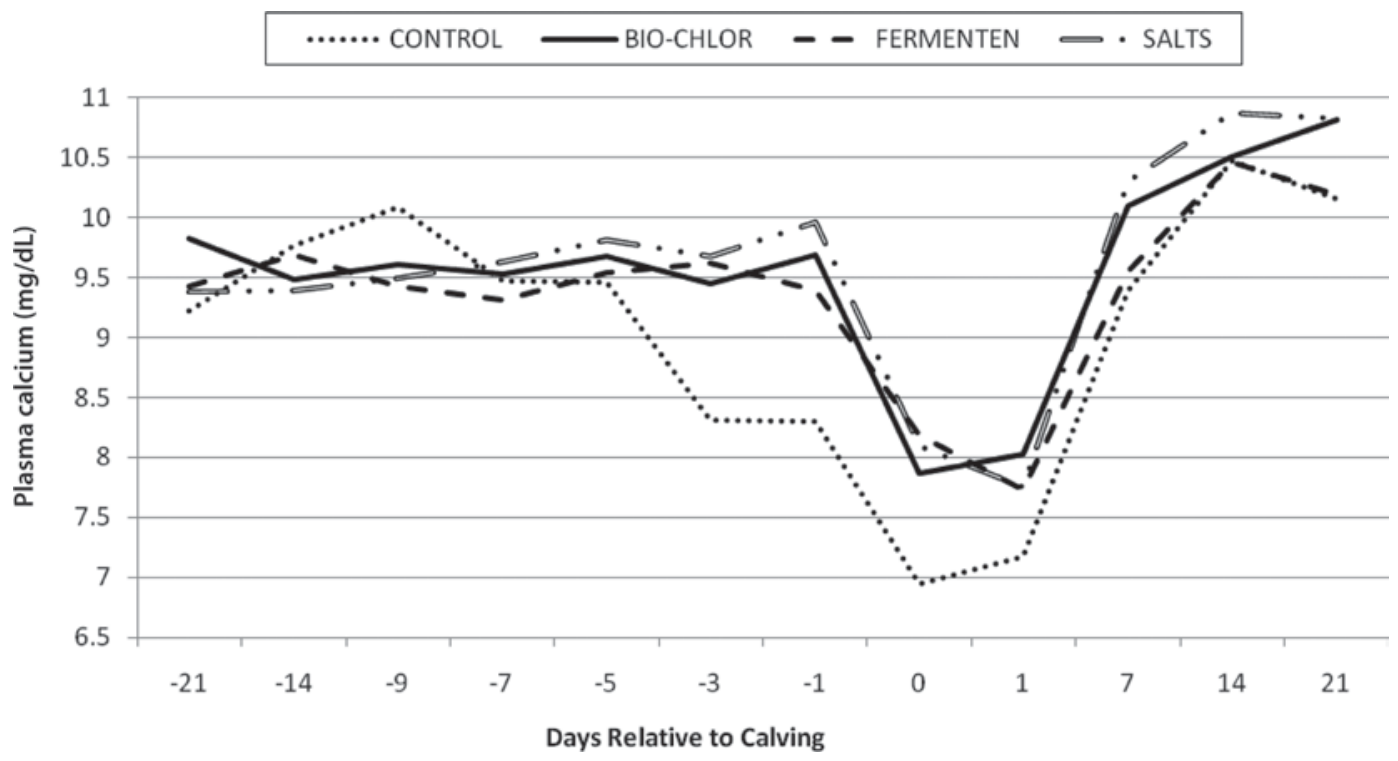

Figure 3. Temporal pattern of concentration of calcium in blood plasma of all cows relative to day of calving $(\mathrm{d} 0)$.

calcium values below $5.5 \mathrm{mg} / \mathrm{dL}$ on the day of parturition; both were multiparous cows fed the control diet. All cows appeared to begin recovering blood calcium immediately after parturition. No clinical cases of hypocalcemia occurred in this trial.

\section{CONCLUSIONS}

Anionic supplements were effective in acidifying prepartum diets based on urine $\mathrm{pH}$, which is an indicator of acid-base status. Prepartum anionic diets were not detrimental to prepartum DMI and did not decrease postpartum performance of primiparous cows. Feeding anionic diets prepartum increased postpartum DMI of both primiparous and multiparous cows and increased milk yield of multiparous cows. However, prepartum anionic diets did not increase plasma Ca of multiparous cows at calving. Other blood minerals and metabolite changes were consistent with parity and stage of pregnancy or lactation but were unaltered by DCAD. On the basis of the current research, cows and heifers can be grouped together during the prepartum period of the transition period and fed an anionic diet without negatively affecting prepartum DMI and postpartum performance.

\section{ACKNOWLEDGMENTS}

The authors acknowledge Church and Dwight Co. Inc. (Princeton, NJ) for their support of this research as well as the staff and students at the Oregon State
University Dairy Center (Corvallis) for their assistance in data collection.

\section{REFERENCES}

Apper-Bossard, E., J. L. Peyraud, P. Faerdin, and F. Meschy. 2006. Changing dietary cation-anion difference for cows fed with two contrasting levels of concentrate in diets. J. Dairy Sci. 89:749760 .

Block, E. 1984. Manipulating dietary anions and cations for prepartum dairy cows to reduce incidence of milk fever. J. Dairy Sci. 67:2939-2948.

Charbonneau, E., D. Pellerin, and G. R. Oetzel. 2006. Impact of lowering dietary cation-anion difference in non-lactating dairy cows: A meta-analysis. J. Dairy Sci. 89:537-548.

Curtis, C. R., H. N. Erb, C. J. Sniffen, R. D. Smith, P. A. Powers, M C. Smith, M. E. White, R. B. Hillman, and E. J. Pearson. 1983. Association of parturient hypocalcemia with eight periparturient disorders in Holstein cows. J. Am. Vet. Med. Assoc. 183:559 561.

Goff, J. P., and R. L. Horst. 1997a. Effect of dietary potassium and sodium, but not calcium, on the incidence of milk fever in dairy cows. J. Dairy Sci. 80:176-186.

Goff, J. P., and R. L. Horst. 1997b. Physiological changes at parturition and their relationship to metabolic disorders. J. Dairy Sci. 80:1260-1268

Goff, J. P., and R. L. Horst. 1998. Factors to concentrate on to prevent periparturient disease in the dairy cow with special emphasis on milk fever. Pages 154-163 in Proc. 31st Conf. of American Association of Bovine Practitioners, Spokane, WA. VM Publishing Company, Stillwater, OK.

Goff, J. P., R. L. Horst, P. W. Jardon, C. Borelli, and J. Wedam 1996. Field trials of an oral calcium propionate paste as an aid to prevent milk fever in periparturient dairy cows. J. Dairy Sci. 79:378-383.

Goff, J. P., R. L. Horst, and T. A. Reinhardt. 1987. The pathophysiology and prevention of milk fever. Vet. Med. 9:943-951.

Goff, J. P., R. Ruiz, and R. L. Horst. 2004. Relative acidifying activity of anionic salts commonly used to prevent milk fever. J. Dairy Sci. $87: 1245-1255$. 
Goings, R. L., N. L. Jacobson, D. C. Beitz, E. T. Littlcdike, and K. D. Wiggers. 1974. Prevention of parturient paresis by a prepartum calcium deficient diet. J. Dairy Sci. 57:1184-1188.

Grummer, R. R. 1993. Etiology of lipid related metabolic disorders in periparturient dairy cows. J. Dairy Sci. 76:3882-3896.

Grummer, R. R. 1995. Impact of changes in organic nutrient metabolism on feeding the transition dairy cow. J. Anim. Sci. 73:28202833.

Guard, C. 1996. Fresh cow problems are costly: Culling hurts the most. Page 100 in Proc. 1994 Annu. Conf. Vet., Cornell Univ., Ithaca, NY.

Gulay, M. S., M. J. Hayen, M. Liboni, T. I. Belloso, C. J. Wilcox, and H. H. Head. 2004. Low doses of bovine somatotropin during the transition period and early lactation improves milk yield, efficiency of production, and other physiological responses of Holstein cows. J. Dairy Sci. 87:948-960.

Hayirli, A., R. R. Grummer, E. V. Nordheim, and P. M. Crump. 2002. Animal and dietary factors affecting feed intake during the prefresh transition period in Holsteins. J. Dairy Sci. 85:3430-3443.

Horst, R. L. J. P. Goff, and T. A. Reinhardt. 1994. Calcium and vitamin D metabolism in the dairy cow. J. Dairy Sci. 77:1936-1951.

Horst, R. L., J. P. Goff, T. A. Reinhardt, and D. R. Buxton. 1997. Strategies for preventing milk fever in dairy cattle. J. Dairy Sci. 80:1269-1280.

Hu, W., L. Kung Jr., and M. R. Murphy. 2007. Relationship between dry matter intake and acid-base status of lactating dairy cows as manipulated by dietary cation-anion difference. Anim. Feed Sci. Technol. 136:216-225.

Hu, W., and M. R. Murphy. 2004. Dietary cation-anion difference effects on performance and acid-base status of lactating dairy cows: A meta-analysis. J. Dairy Sci. 87:2222-2229.

Huyler, M. T., R. L. Kincaid, and D. F. Dostal. 1999. Metabolic and yield responses of multiparous Holstein cows to prepartum rumenundegradable protein. J. Dairy Sci. 82:527-536.

Joyce, P. W., W. K. Sanchez, and J. P. Goff. 1997. Effect of anionic salts in prepartum diets based on alfalfa. J. Dairy Sci. 80:28662875 .

Keady, T. W. J., C. S. Mayne, D. A. Fitzpatrick, and M. A. McCoy. 2001. Effect of concentrate feed level in late gestation on subsequent milk yield, milk composition, and fertility of dairy cows. J. Dairy Sci. 84:1468-1479.

Lean, I. J., P. J. Degaris, D. M. McNeil, and E. Block. 2006. Hypocalcaemia in dairy cattle: Meta-analysis and dietary cation-anion difference theory revisited. J. Dairy Sci. 89:669-684.

Lean, I. J., T. B. Farver, H. F. Troutt, M. L. Bruss, J. C. Galland, R. L. Baldwin, C. A. Holmberg, and L. D. Weaver. 1992. Time series cross-correlation analysis of postparturient relationships among serum metabolites and yield variables in Holstein cows. J. Dairy Sci. $75: 1891-1900$.

Lean, I. J., T. K. Miller Webster, W. Hoover, W. Chalupa, C. J. Sniffen, E. Evans, E. Block, and A. R. Rabiee. 2005. Effects of BioChlor and Fermenten on microbial protein synthesis in continuous culture fermenters. J. Dairy Sci. 88:2524-2536.

Moore, S. J., M. J. VandeHaar, B. K. Sharma, T. E. Pilbeam, D. K. Beede, H. F. Bucholtz, J. S. Liesman, R. L. Horst, and J. P. Goff. 2000. Effects of altering dietary cation-anion difference on calcium and energy metabolism in peripartum cows. J. Dairy Sci 83:2095-2104.

National Research Council. 2001. Nutrient Requirements of Dairy Cattle. 7th rev. ed. Natl. Acad. Sci., Washington DC.

Phillippo, M., G. W. Reid, and I. M. Nevison. 1994. Parturient hypocalcemia in dairy cows: Effects of dietary acidity on plasma minerals and calciotrophic hormones. Res. Vet. Sci. 56:303-309.

Piepenbrink, M. S., A. L. Marr, M. R. Waldron, W. R. Butler, T. R. Overton, M. Vázquez-Añón, and M. D. Holt. 2004. Feeding 2-hydroxy-4(methylthio)-butanoic acid to periparturient dairy cows improves milk production but not hepatic metabolism. J. Dairy Sci. 87:1071-1084.

Sanchez, W. K., D. K. Beede, and J. A. Cornell. 1994. Interactions of sodium, potassium, and chloride on lactation, acid-base status, and mineral concentrations. J. Dairy Sci. 77:1661-1675.

SAS Institute. 2001. SAS User's Guide: Statistics. Version 8 ed. SAS Inst. Inc., Cary, NC.

Spanghero, M. 2004. Prediction of blood and urinary pH in non-lactating dairy cows fed anionic diets. Anim. Feed Sci. Technol. 116:83-92.

USDA. 2007, Part I: Reference of Dairy Cattle Health and Management Practices in the United States. \#N480.1007. USDA-APHISVS, CEAH, Fort Collins, CO.

Vagnoni, D. B., and G. R. Oetzel. 1998. Effects of dietary cationanion difference on the acid-base status of dry cows. J. Dairy Sci. 81:1643-1652.

Veenhuizen, J. J., J. K. Drackley, M. J. Richard, T. P. Sanderson, L. D. Miller, and J. W. Young. 1991. Metabolic exchanges in blood and liver during development and early treatment of experimental fatty liver and ketosis in cows. J. Dairy Sci. 74:4238-4253.

Weiss, W. P., H. R. Conrad, and N. R. St-Pierre. 1992. A theoreticallybased model for predicting total digestible nutrient values of forages and concentrates. Anim. Feed Sci. Technol. 39:95-110.

Wildman, E. E., G. M. Jones, P. E. Wagner, R. L. Boman, H. F. Troutt Jr., and T. N. Lesch. 1982. A dairy cow body condition scoring system and its relationship to selected production characteristics. J. Dairy Sci. 65:495-501. 